
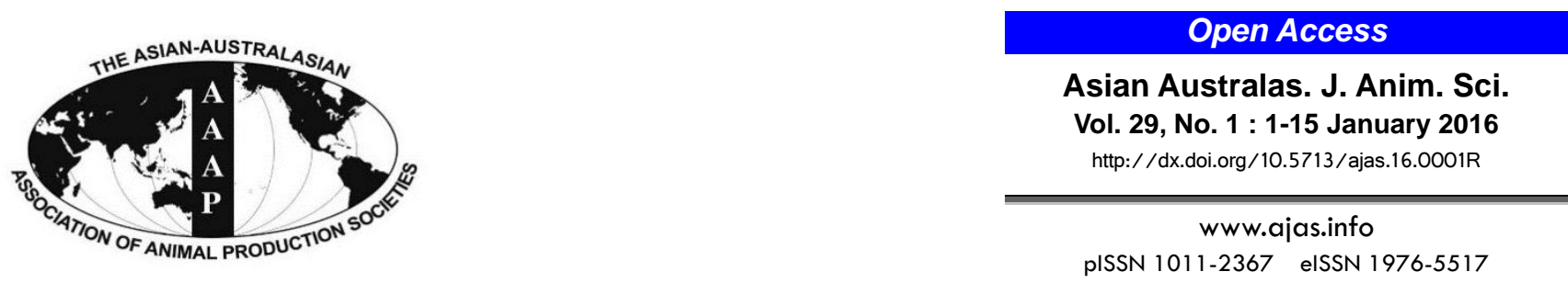

\title{
- Invited Review - Physiological Roles of Adipokines, Hepatokines, and Myokines in Ruminants
}

\author{
Sang-Gun Roh*, Yutaka Suzuki, Takafumi Gotoh ${ }^{1}$, Ryuichi Tatsumi ${ }^{2}$, and Kazuo Katoh \\ Lab of Animal Physiology, Graduate School of Agricultural Science, Tohoku University, Sendai 981-8555, Japan
}

\begin{abstract}
Since the discovery of leptin secreted from adipocytes, specialized tissues and cells have been found that secrete the several peptides (or cytokines) that are characterized to negatively and positively regulate the metabolic process. Different types of adipokines, hepatokines, and myokines, which act as cytokines, are secreted from adipose, liver, and muscle tissue, respectively, and have been identified and examined for their physiological roles in humans and disease in animal models. Recently, various studies of these cytokines have been conducted in ruminants, including dairy cattle, beef cattle, sheep, and goat. Interestingly, a few cytokines from these tissues in ruminants play an important role in the post-parturition, lactation, and fattening (marbling) periods. Thus, understanding these hormones is important for improving nutritional management in dairy cows and beef cattle. However, to our knowledge, there have been no reviews of the characteristics of these cytokines in beef and dairy products in ruminants. In particular, lipid and glucose metabolism in adipose tissue, liver tissue, and muscle tissue are very important for energy storage, production, and synthesis, which are regulated by these cytokines in ruminant production. In this review, we summarize the physiological roles of adipokines, hepatokines, and myokines in ruminants. This discussion provides a foundation for understanding the role of cytokines in animal production of ruminants. (Key Words: Ruminant, Adipokine, Hepatokine, Myokine)
\end{abstract}

\section{INTRODUCTION}

Endocrine systems are important for the growth and development of animals. Understanding the regulation and control of hormones secreted from endocrine organs is important in animal production. Since the physiological functions of the hormones identified have been reported in humans and rodents, domestic animals have been examined in numerous studies. Ruminants have distinct glucose and lipid metabolisms; volatile fatty acids produced by rumen fermentation are utilized as substrates (Roh et al., 2006). Adipose tissue is synthesized mainly from long-chain fatty acids, triglycerides from acetic acid, and endogenous glucose

\footnotetext{
* Corresponding Author: Sang-Gun Roh. Tel: +81-22-717-8698, Fax: +81-22-717-8701, E-mail: sanggun.roh.a3@tohoku.ac.jp

${ }^{1}$ Kuju Agriculture Research Center, Kyushu University, Oita 878020, Japan.

2 Department of Animal and Marine Bioresource Sciences, Graduate School of Agriculture, Kyushu University, Fukuoka 8128581, Japan.

All authors contributed equally to this paper.
}

by de novo synthesis through gluconeogenesis from propionate in the liver. The capacity of lipid synthesis in adipocytes of ruminants is high compared to that in other species. Excess energy is stored as triglycerol, which is broken down into glycerol and fatty acids (Yonekura et al., 2014; Choi et al., 2015). Fatty acids are consumed as an energy source in the peripheral tissues. Energy metabolism in ruminants, which mainly use lipid for energy, affects economic traits such as milk production and milk quality in dairy cattle as well as marbling in beef cattle. Despite the importance of adipose tissue in energy homeostasis, excess fat depots negatively influence the grading of carcasses, and they are therefore trimmed (Belk et al., 1991; Vernon et al., 2001). In contrast, the presence of intramuscular adipocytes is a desirable characteristic (known as marbling). The metabolism of adipose tissue plays a critical role in the support of reproduction and lactation of ruminants and is related to ketosis and fatty liver caused by a negative energy balance, described as a metabolic state in which energy is lacking (Pethick and Lindsay, 1982; Bell, 1995; Laliotis et al., 2010). Thus, the energy metabolism of adipose tissue is 
a very important target in animal science. Dairy cows exert intense energy during parturition because of the onset of copious milk synthesis; however, feed intake is reduced during this time. Previous studies have mainly examined endocrine systems in organs, such as the pituitary and pancreas, the gonads, and adrenal gland. However, the endocrine characteristics of adipose, liver, and muscle tissues as productive organs have not been widely examined in ruminants.

Cytokines were initially found to play a key role in immune system balance and the response to infectious pathogens. In early 1980, cytokines were found to be secreted proteins; they were found to regulate important cellular responses such as proliferation and differentiation in several tissues (Nicola, 1994). The balance between cytokine synthesis and secretion from immune cells has become a focus of research characterizing the immune response in ruminants. "Cyto" means cells, whereas "kine" means active protein. Hormones or cytokines secreted from endocrine organs such as epithelial cells and immune cells have been reported.

These cytokines, particularly those secreted from adipose, liver, and muscle tissues, regulate glucose, lipid, and protein metabolism related to beef and dairy products. Lactation, meat production, growth, and pregnancy in ruminants are processes with high energy and protein demands. Feed intake and nutrient utilization related to animal production in ruminants may be strictly controlled by several different types of cytokines. In addition, abnormal secretions and the functional relationships between these cytokines have been observed in many diseases, such as fatty liver, ketosis, acidosis (caused an energy and nutrient imbalance), and metabolic disorders in ruminant production systems. Understanding the physiological roles of adipokines, hepatokines, and myokines in ruminants helps to improve animal health and the quality and quantity of animal production. In this review, we discuss the metabolism of ruminants and the important physiological roles of adipokines, hepatokines, and myokines.

\section{Adipokines}

Adipokines are proteins that are secreted from the adipose tissue as endocrine factors from adipocytes and/or non-adipocytes. Several adipokines have been identified by numerous different groups. It is thought that many adipokines show increased expression and secretion with the development of adipose tissues and can sense long-term changes in energy balance, regulate feeding and metabolism, and maintain homeostasis in the body. Therefore, adipokines modulate various biological functions such as energy metabolism and immune response with other hormones in animal production (Baik et al., 2014; Kang et al., 2015). We summarize the novel findings regarding the major adipokines, including leptin, adiponectin, tumor necrosis factor (TNF)- $\alpha$, and chemerin.

\section{Leptin}

Leptin was first identified as an adipokine secreted from adipocytes in adipose tissues (Zhang et al., 1994). Leptin inhibits food intake and increases energy expenditure through its receptors in the brain. Several studies have examined leptin secretion in ruminants.

Plasma leptin is positively correlated with muscle lipid content for continental crossbred steer of $0 \%$ Wagyu, but there was almost no correlation in these parameters for crossbred cattle of 50\% Wagyu (Wegner et al., 2001). Fatter cows show higher plasma leptin concentrations prepartum, a more pronounced decrease in leptin concentration near calving, and higher plasma leptin concentrations after calving (Kokkonen et al., 2005). Concentrations of leptin with insulin-like growth factor (IGF)-1 and insulin in fed and fasted cows were positively correlated with body condition score (Lents et al., 2005). Serum concentrations of leptin were significantly associated with carcass composition (marbling, back fat depth, and kidney, pelvic, and heart fat) and quality grade in crossbred Bos taurus steers and heifers (Geary et al., 2003). Growth hormone (GH)-transgenic and control sheep showed similar leptin secretion, despite differences in body condition and basal levels of these hormones (Kadokawa et al., 2003). This evidence suggests that leptin is related to body fatness in ruminants.

Uncoordinated increases in plasma IGF-1 during growing periods and plasma leptin during fattening periods indicate i) the indirect involvement of endogenous IGF-1 on leptin secretion and ii) that IGF-1 level may signify lean and bone accretion, while plasma leptin may mirror body fatness in the monthly ages of Holstein steers (Vega et al., 2002). Changes in plasma IGF-1 levels with increased live weight may be related to changes in plasma IGF binding protein (IGFBP)-3 levels, and IGFBP-2 may have an important role in the anabolic action of IGF-1 with body growth during calfhood in Holstein steers (Lee et al., 2005b).

In sheep, body fatness or body condition score and plasma leptin levels and concentrations of leptin over time were found to be significantly positively correlated, with underfed ewes exhibiting a dramatic reduction in plasma leptin levels (Delavaud et al., 2000). In diet-restricted lambs treated with leptin or saline, the mean GH did not differ on day 0 , but increased in response to leptin treatment (Morrison et al., 2001). Treatment of fed lambs with leptin did not affect serum GH. Leptin also regulates the secretion of GH in sheep and cattle (Roh et al., 1998; Roh et al., 2001; Zieba et al., 2003). Roh et al. (2001) reported observed a negative effect of leptin on GH-releasing hormone (GHRH)-stimulated GH 
secretion with reduced GHRH receptor synthesis in somatotrophs from ovine primary cell cultures. Furthermore, leptin inhibited the dose-dependent increase in GHRHmediated $\mathrm{GH}$ release in the tissues of normal-fed cows (Zieba et al., 2003). However, in explants harvested from fasted cows, leptin did not affect GHRH-mediated GH release (Zieba et al., 2003). This suggests that leptin can act directly at the anterior pituitary level to modulate GH release depending upon nutritional status.

\section{Adiponectin}

Adiponectin is involved in improving insulin sensitivity (Berg et al., 2001; Yamauchi et al., 2001), regulating fatty acid metabolism (Fruebis et al., 2001), cell proliferation (Brakenhielm et al., 2004; Bub et al., 2006), and differentiation (Luo et al., 2005) in various cells. In particular, its expression is markedly increased during adipocyte differentiation in mice and ruminants (Scherer et al., 1995; Roh et al., 2006). Adiponectin regulates various physiological functions by activating adenosine monophosphate (AMP)-activated protein kinase (AMPK), which is mediated by two subtypes of adiponectin receptors (AdipoRs), including AdipoR1 and AdipoR2. In cattle, adiponectin mRNA is highly expressed in adipose tissues and is upregulated during adipocyte differentiation of preadipocytes derived from bovine stromal-vascular cells (Feuermann et al., 2006; Soliman et al., 2007). Moreover, adiponectin mRNA expression in adipose tissue is lower in lactating cows than in non-lactating cows (Komatsu et al., 2003; Komatsu et al., 2007). Our group previously reported that bovine adiponectin and its receptor genes were expressed in various tissues, particularly in mammary tissues, and expression levels were changed during the lactation cycle (Ohtani et al., 2011). Increased serum adiponectin may be involved in energy metabolism near parturition, and it may exert its action by regulating receptor expression levels in target tissues during each lactational stage in Holstein dairy cows (Ohtani et al., 2012).

\section{Tumor necrosis factor- $\alpha$}

TNF- $\alpha$, a major pro-inflammatory cytokine produced in macrophages, mast cells, and other immune cells, induces the production of inflammatory cytokines, chemokines, and angiogenic factors by activating mitogen-activated protein kinases (MAPK) and the nuclear factor (NF)- $\kappa \mathrm{B}$ pathway (Aggarwal, 2003). In humans, TNF- $\alpha$ inhibits leptin release from cultured subcutaneous and omental adipocytes (Fawcett et al., 2000). TNF- $\alpha$ decreased leptin production and gene expression during incubation of abdominal subcutaneous adipose tissue in vitro (Bruun et al., 2002). The production and secretion of TNF- $\alpha$ in adipose tissue is unclear in ruminants. TNF- $\alpha$ upregulated chemerin and chemerin receptor gene expression in bovine cultured adipocytes (Song et al., 2010). Administration of TNF- $\alpha$ also promoted insulin resistance in steers (Kushibiki et al., 2001a;b). In cattle, TNF- $\alpha$ administration was followed by an initial increase in circulating concentrations of glucose followed by prolonged hypoglycemia (Kenison et al., 1991; Kushibiki et al., 2000). TNF- $\alpha$ administration also caused an initial increase in triglycerides, followed by decreased circulating concentrations of triglycerides in heifers (Kushibiki et al., 2000). Others, however, have observed that triglycerides and nonesterified fatty acids were not affected by TNF- $\alpha$ treatment of bull calves (Kenison et al., 1991). Circulating plasma concentrations of TNF- $\alpha$ are greater in fat ewes, suggesting that an additional mechanism exists for fat cell signaling of the body condition (Daniel et al., 2003).

The p38-inhibitor SB203580 suppresses TNF- $\alpha$-induced interleukin (IL)-6 and IL-8 production in Sertoli cells and bronchial epithelial cells, respectively, highlighting the role of this pathway in inflammatory cytokine production (De Cesaris et al., 1998; Matsumoto et al., 1998). In addition to MAPKs, the NF- $\kappa$ B pathway is widely known to be another potent signaling pathway leading to cytokine production and has been reported to interact with MAPK pathways (Aggarwal, 2003; Starace et al., 2008).

The role of TNF- $\alpha$ is not limited to the induction of cytokine production. It also has a large influence on adipocyte metabolism. The lipolytic effect of TNF- $\alpha$ is a potent property in adipocytes. TNF- $\alpha$ induces the activation of extracellular signal-regulated kinase (ERK) 1/2, JNK (cjun N-terminal kinase), AMPK, and PKA (cyclic AMPdependent protein kinase), which are involved in the mechanism of TNF- $\alpha$-induced lipolysis (Cawthorn and Sethi, 2008). Not only does TNF- $\alpha$ induce lipolysis, but also inhibits fatty acid uptake and lipogenesis in adipocytes. TNF$\alpha$ downregulates the expression of fatty acid transport protein (FATP), FAT, and lipoprotein lipase (LPL) to decrease adipocyte uptake of free fatty acids (Memon et al., 1998; Ruan et al., 2002; Ruan et al., 2003). Downregulation of lipogenic enzymes, including acetyl CoA synthetase (ACC), fatty acid synthetase (FASN), and fatty acid binding protein 4 (FABP4), by TNF- $\alpha$ causes decreased lipogenesis in adipocytes (Cawthorn and Sethi, 2008). In addition, TNF- $\alpha$ impairs adipogenesis. Adipogenesis is driven by a transcriptional cascade which is characterized by early transient expression of CCAAT/enhancer binding protein $\beta$ $(\mathrm{C} / \mathrm{EBP} \beta)$ or $\mathrm{C} / \mathrm{EBP} \delta$ followed by $\mathrm{C} / \mathrm{EBP}$ and peroxisome proliferator-activated receptor $\alpha(\operatorname{PPAR} \alpha)$. TNF- $\alpha$ prevents $\mathrm{C} / \mathrm{EBP} \alpha$ and PPAR $\gamma$ activation via ERK or JNK, resulting in the inhibition of adipogenesis (Cawthorn and Sethi, 2008).

\section{Chemerin}

Chemerin was first identified as a gene expressed in non- 
lesional skin in psoriasis. Chemerin's role as a natural ligand for chemokine receptor-like 1 (CMKLR1) and the effect of promoting the migration of leukocytes was later reported (Wittamer et al., 2003; Wittamer et al., 2004; Wittamer et al., 2005). Our group reported that chemerin is an adipokine expressed and secreted in fat cells (Roh et al., 2007). Two other groups reported that chemerin is an adipokine (Bozaoglu et al., 2007; Goralski et al., 2007). Chemerin is secreted as the inactive $18-\mathrm{kDa}$ precursor prochemerin, processed by serine proteases (elastase, tryptase, cathepsin G) in the blood, and converted into several forms of active chemerin. Chemerin has been reported to be associated with inflammation and metabolic syndrome in mouse and human studies (Bozaoglu et al., 2009; Hu and Feng, 2011). Chemerin mRNA and protein expression was increased by adipocyte differentiation, and up-regulated in the adipose tissue of mice fed a high-fat diet. Additionally, chemerin levels are increased by insulin resistance and glucose intolerance in the skeletal muscle and liver. Chemerin also functions as a chemotactic factor and shows increased concentrations in inflammatory situations. TNF- $\alpha$, IL-6, and C-reactive protein have been correlated with the blood concentration of chemerin. Therefore, chemerin is associated with metabolic syndrome and chronic inflammation in the adipose tissue in obesity and type 2 diabetes. Because of the differences in glucose and lipid metabolism of ruminants compared with in monogastric animals, chemerin was also suggested to have a role as an endocrine factor.

We first reported the endocrine and metabolic changes in response to chemerin in sheep (Suzuki et al., 2012b). Our previous results suggested that a chemerin analog $\left(\mathrm{NH}_{2}-\right.$ yFLPsQFa(Tic)S-COOH) regulated insulin secretion related to glucose metabolism and the release of triglycerides in sheep in vivo. In addition, chemerin analog treatment was shown to upregulate chemerin gene expression levels regardless of the dose in bovine cultured adipocytes in vitro (Suzuki et al., 2012a). Our data clearly showed that TNF- $\alpha-$ induced activation of the MAPK pathway is a potent pathway regulating chemerin expression in bovine differentiated adipocytes. (Figure 1A). Treatment of TNF- $\alpha(10 \mathrm{ng} / \mathrm{mL})$ clearly induced phosphorylation of ERK1/2 after $5 \mathrm{~min}$ stimulation, which was later attenuated. Low JNK phosphorylation was observed at $5 \mathrm{~min}$, but phosphorylation levels were high at $15 \mathrm{~min}$ after TNF- $\alpha$ treatment. p38 MAPK was phosphorylated at 5 and 15 min. Furthermore, the MAPK inhibitors PD98059, SP600125, and SB203580 were used to attenuate the phosphorylation of their target MAPK protein (Figure 1B). PD98059 and SP600125 suppressed the phosphorylation of ERK1/2 and JNK, respectively. SB203580 did not suppress the activation of p38 MAPK induced by TNF- $\alpha$. In addition, MAPK inhibitors blocked TNF- $\alpha$-induced up-regulation of chemerin and CMKLR1 expression. Three hours after TNF- $\alpha$ treatment,

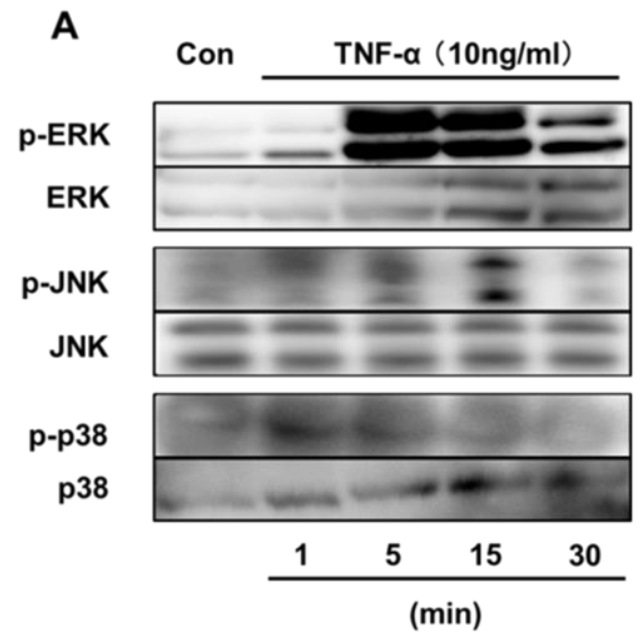

B

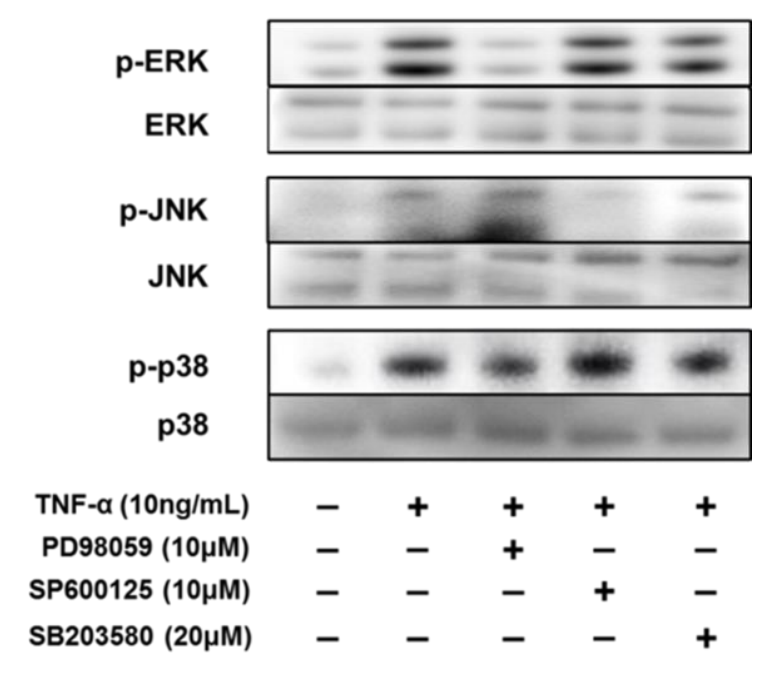

Figure 1. Effect of each inhibitor on TNF- $\alpha$-induced MAPK activation in bovine differentiated adipocytes. (A) Differentiated bovine adipocytes were incubated in serum-free DMEM/HAMF12 for $3 \mathrm{~h}$ before treatment with TNF- $\alpha(10 \mathrm{ng} / \mathrm{mL})$ for the indicated times. (B) Differentiated bovine adipocytes were pre-incubated with each MAPK inhibitor for $1 \mathrm{~h}$ followed by treatment with TNF$\alpha(10 \mathrm{ng} / \mathrm{mL})$. Whole soluble protein was extracted and used for western blot analysis of total and phosphorylated ERK, JNK, or $\mathrm{p} 38$. TNF- $\alpha$, tumor necrosis factor- $\alpha$; MAPK, mitogen-activated protein kinase; ERK, extracellular signal-regulated kinase; JNK, cjun $\mathrm{N}$-terminal kinase.

the gene expression of chemerin was upregulated, and this up-regulation was attenuated by SB203580 (Figure 2A). Similarly, the TNF- $\alpha$-induced up-regulation of CMKLR1 expression was suppressed by SB203580 at $3 \mathrm{~h}$ after treatment (Figure 2B).

Chemerin has a significant influence on carcass traits. Regarding the single nucleotide polymorphism (SNP) of chemerin, c. $276 \mathrm{C}>\mathrm{T}$, we found that cattle with genotype CC had a higher beef marbling score than that of cattle with genotype CT, whereas cattle with genotype CT had a higher body condition score $(\mathrm{p}<0.10)$ (Yamauchi et al., 2015). 
A

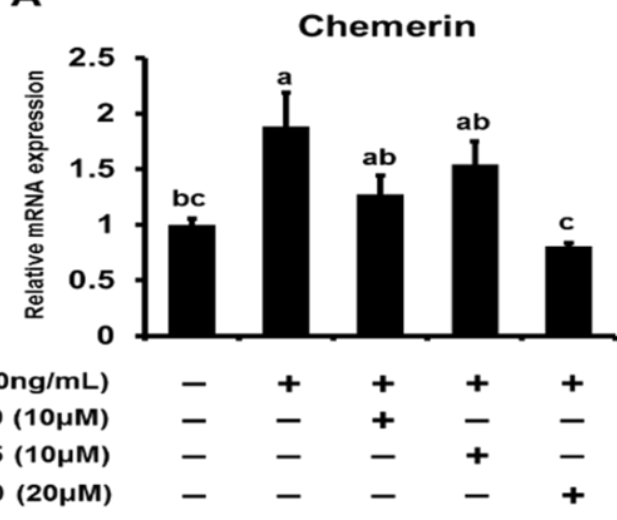

B

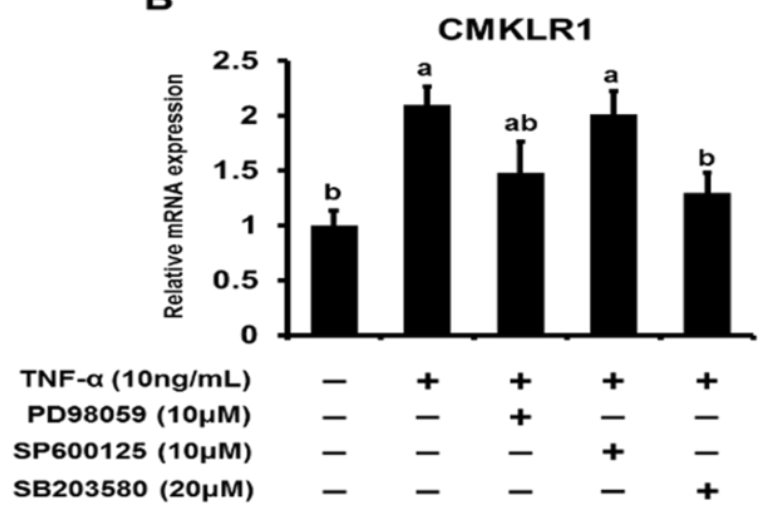

Figure 2. Inhibition of TNF- $\alpha$-induced upregulation of cheme rin and CMKLRl gene expression in differentiated bovine adi pocytes. Cells were incubated with serum-free DMEM/HAMF 12 for $2 \mathrm{~h}$ before treatment. Cells were pretreated with vehic le (DMSO) or MAPKs inhibitors (PD98059, SP600125, or S B203580) for $1 \mathrm{~h}$, and then stimulated with TNF- $\alpha$ for $3 \mathrm{~h}$ (A, B). After treatment for $3 \mathrm{~h}$, the expression levels of che merin and CMKLR1 gene were analyzed by qRT-PCR. Gene expression was normalized with ALAS1 and represented as $t$ he mean $\pm \operatorname{SEM}(n=6)$. ${ }^{\text {abc }}$ Significant differences $(\mathrm{p}<0.05)$ between values for each treatment concentration are denoted with letters. CMKLR1, chemokine receptor-like 1 ; TNF- $\alpha$, tumor necrosis factor- $\alpha$; MAPK, mitogen-activated protein kinase; ALAS1, aminolevulinate synthase 1 .

Further, cattle with genotype $\mathrm{CC}$ had significantly higher C18:0 content in their intramuscular fat tissue than cattle with genotype $\mathrm{CT}(\mathrm{p}<0.05)$. In contrast, cattle with genotype CT had significantly higher C14:0 and C16:0 content in their intramuscular fat tissue. Moreover, the number of individuals carrying the minor allele of c.276C $>\mathrm{T}$ SNP is small. This suggests that the c.276C > T SNP of the chemerin gene could be used for cattle breeding using modern methods, such as marker-assisted selection. Thus, further functional and physiological studies examining the impact of the chemerin gene on bovine lipid metabolism including fatty acid synthesis improve our understanding of these traits.

\section{HEPATOKINES}

Hepatokines were first introduced as the protein selenoprotein $\mathrm{P}$, which contributes to the development of insulin resistance in the liver and skeletal muscle (Misu et al., 2010). Before this report, several studies showed that hepatic secretory factors, including the angiopoietin-like protein family (Oike et al., 2005; Xu et al., 2005), fetuin-A (Auberger et al., 1989; Srinivas et al., 1993), and angiopoietin-like protein 8 (ANGPTL8)/betatrophin (Yi et al., 2013), are hepatokines involved in insulin sensitivity.

The livers of ruminants play very important roles in glucose and lipid metabolism and contribute to body maintenance and production (Stefan and Haring, 2013). In addition, the liver is a passive organ that is altered by nutrient availability such as feeding and fasting. Mobilization of nonesterified fatty acids from white adipose tissue is both intensive and extensive, with rates peaking as high as 3,712 $\mathrm{g} / \mathrm{d}$ after parturition; these rates are sustained over the first month of lactation to cover $30 \%$ of the total energy requirement (Drackley et al., 2001; Vernon, 2005; Schoenberg et al., 2011). Glucose is mainly synthesized in the liver via gluconeogenesis from propionate absorbed from the rumen. The negative energy balance induced by parturition induced fatty liver via increased lipolysis in adipocytes, resulting in the accumulation of FFA in the livers of lactating cow (Goff and Stabel, 1990; Bobe et al., 2004). Some dairy cows are susceptible to pathologies such as fatty liver in early lactation (Goff and Stabel, 1990; Bobe et al., 2004). Dysregulation of nutrient signals among adipose, liver, and muscle tissues can result in chronic metabolic diseases. However, the identification of hepatokines redefined the liver as an endocrine organ that regulates the metabolism of other tissues. Several peptides have been shown to be secreted from the liver tissue and hepatocytes.

\section{Insulin-like growth factors}

Many scientists first identified IGF-1 as a hepatokine, because injected radiolabeled GH rapidly localizes to the liver and produces growth factors with insulin-like properties. IGFs were given a name that reflects the structural relationship with proinsulin and show some affinity for insulin receptors. IGF-1 secretion in liver tissue is stimulated by GH secreted from the pituitary gland. In addition, IGF-I is expressed in many tissues; however, most IGF-1 in the blood is secreted from the liver. The biological effects of IGFs are induced by IGF binding proteins (IGFBPs).

Interestingly, in cattle, administration of IGF-1 increased milk production in lactating cows and body weight in beef cattle. In ruminants, circulating IGF-1 is positively correlated with growth (Roberts et al., 1990) and growth rate (Bishop et al., 1989). Studies in ruminants have shown that nutrition and the treatment of chronic and acute GH regulate IGF-1 
secretion and positive and negative circulation of IGFBPs (Vicini et al., 1991; Stanko et al., 1994; McCann et al., 1997). Protein restriction decreased plasma IGF-1 concentrations and increased 34-kDa IGFBP-2 levels in low protein (LP; crude protein $0.66 \mathrm{~kg} / \mathrm{d}$ and total digestible nutrients 4.42 $\mathrm{kg} / \mathrm{d}$ dry matter intake) steers (Lee et al., 2005a).

\section{Serenoprotein $\mathbf{P}(\mathrm{SeP})$}

SeP (in humans encoded by the SEPPI gene) is a secreted protein primarily produced by the liver (Carlson et al., 2004; Burk and Hill, 2005). SeP contains ten selenocysteine residues and functions as a selenium-supplying protein (Saito et al., 1999). SeP induces insulin resistance and hyperglycemia, indicating that this protein is a therapeutic target for insulin resistance-associated diseases, including type 2 diabetes (Misu et al., 2010). Our unpublished data showed that SeP mRNA expression was inhibited by insulin treatment for $24 \mathrm{~h}$ in bovine cultured hepatocytes.

\section{Chemerin}

Because our data indicate that chemerin is expressed and produced by the liver and has a regulatory role in metabolism, we suggest that chemerin should be referred to as an adipokine.

Previous studies have investigated the regulation of hepatic chemerin expression and secretion mainly in mice. High-fat diet feeding significantly elevates chemerin transcription but not protein expression in the mouse liver (Krautbauer et al., 2013). In the two mice models of fatty liver disease, hepatic chemerin expression was also altered. Paigen diet feeding, which contains higher cholesterol content resulting in non-alcoholic fatty liver disease, generally increases hepatic chemerin protein (Krautbauer et al., 2013). Methionine choline-deficient (MCD) diet feeding, which lacks methionine and choline and induces more severe fatty liver (non-alcoholic steatohepatitis), elevates local chemerin protein production in the liver but does not increase systemic chemerin levels (Krautbauer et al., 2013). Accordingly, in human patients with non-alcoholic fatty liver disease and non-alcoholic steatohepatitis, hepatic chemerin was also increased (Docke et al., 2013). Recent studies using cultured hepatocytes revealed the regulatory factors of chemerin expression related with lipid and cholesterol metabolism, including long-chain fatty acid, cytokines, metofolmin, and FXR agonist (Deng et al., 2013; Krautbauer et al., 2013). These data suggests that hepatic chemerin is involved in lipid metabolism and inflammation in the liver.

Hepatic chemerin expression in bovine, however, may be modulated by other factors than those in mouse and human. We found that chemerin protein expression was decreased in the liver of post-weaning calves compared to pre-weaning calves without transcriptional changes (unpublished data).
Furthermore, chemerin mRNA and protein are more abundant in the liver of growing calves (10 months of age) fed a concentrated diet than calves fed only haylage (Suzuki et al., 2015). Although insulin and propionate were shown to negatively regulate hepatic chemerin transcription in bovine hepatocytes, the detailed mechanism remains unclear (Suzuki et al., 2014). Thus, the physiological role of chemerin in the metabolism in the liver differs between ruminants and rodents because of the differences in regulatory factors of chemerin expression (lipid metabolism vs glucose metabolism).

\section{Angiopoietin-like protein 8/betatrophin}

Angiopoietin-like protein 8 (ANGPTL8) was first reported to be involved with pancreatic $\beta$ cell proliferation in a mouse model of insulin resistance and named betatrophin based on its function (Yi et al., 2013). However, independent groups of researchers that the hormone is not required for $\beta$ cell function or growth (Wang et al., 2013; Gusarova et al., 2014). Another group also demonstrated that in mice with extremely elevated ANGPTL8 expression (26-fold increase), beta cell replication was not significantly altered (Cox et al., 2015). The major physiological role of ANGPTL8 is considered lipid metabolism regulation. Experiments using mice with ANGPTL8 deletion and ANGPTL8 overexpression showed that ANGPTL8 controls and regulates triglyceride levels with no abnormalities in glucose homeostasis (Wang et al., 2013; Gusarova et al., 2014). Based on these reports, we investigated the regulatory expression of ANGPTL8 in ruminants because ruminant such as cattle and sheep have shown increasing insulin resistance. Our unpublished data showed that ANGPTL8 is highly expressed in the liver and adipose tissues, and its expression is up-regulated by insulin in cultured hepatocytes prepared from pre-weaning Japanese Black cattle. However, the expression was unchanged by increasing fat accumulation in castrated Korean Native cattle (our unpublished data). This suggests that ANGPTL8 is regulated by insulin signaling, not by fat accumulation in cattle.

\section{Fibroblast growth factor 21}

Fibroblast growth factor (FGFs) are signaling proteins of 150-300 amino acids with diverse biological functions mainly related to development and metabolism. FGF21 is abundantly expressed in the liver. Hepatic FGF21 expression is likely induced during fasting through the activation of PPAR $\alpha$ by non-esterified fatty acids that are released from adipocytes and taken up by hepatocytes (Murata et al., 2011). Boisclair's group at Cornell University first reported the physiological roles in FGF21 in dairy cows. Energy deficiency during early lactation in dairy cows is associated with increased liver FGF21 production and plasma FGF21, and lactation affects $\beta$-Klotho (co-factor of FGF receptor) 
and FGF receptor expression in the liver but not in the white adipose tissue and that the mammary gland is not an FGF21 target tissue (Schoenberg et al., 2011).

\section{MYOKINES}

Skeletal muscle is the largest organ in the body of livestock like cattle, which is closely related to meat quantity and quality (Gotoh et al., 1999; Gotoh, 2003). In livestock industries, skeletal muscles alter the meat characteristics during slaughter. The formation of skeletal muscle was based on nutrition. Skeletal muscle has been a focus of animals, including humans, for feeding or fattening. However, it was recently found that skeletal muscle is also an important secretary organ, affecting metabolism in the animal body. Understanding the secretary functions of muscle is important for feeding systems and nutrition.

In the field of human medicine, continuous physical activity exercises have positive effects on the organs. Exercise mainly affects skeletal muscle, which is the largest organ in the body and characterized by mechanical activities such as posture and movement. Recent epidemiology studies have suggested that skeletal muscle can contribute to extending the period of life (Samitz et al., 2011). It is thought that exercise burns fat and improves obesity, preventing metabolic syndrome. However, exercise also affects many other diseases, such as by preventing Alzheimer disease, controlling melancholy, decreasing stroke, improving liver function, increasing liver function, increasing the immune system, improving arteriosclerosis, improving of bone density, declining the incidence of cancer, and improving and preventing cardiovascular disease (Doroudgar and Glembotski, 2011; Stefan and Haring, 2013). Exercise of muscle not only has the sub-effects of weight loss, but also has positive and direct mechanisms in health improvement. In recent years, it was reported that muscle secretes several hormone-like cytokines. Thus, muscle is a secretory organ. These cytokines produced in muscle are collectively referred to as "myokines" (Pedersen et al., 2007). However, myokines have not yet been internationally defined or have a common understanding. Muscle has been recognized as a motive organ; however, muscle was recently found to function in maintaining homeostasis in the body as a secretary organ.

Myokines are classified into 4 categories: i) myokines secreted by acute contraction stimulus, ii) myokines secreted by chronic motion, iii) myokines secreted by other stimulus except for muscle contraction, and iv) myokines secreted constitutively in muscle. More than 20 myokines have been reported. However, there have been few studies of myokines in livestock. In this section, we focus myokines that have been recently investigated in basic science studies.

\section{Interleukin-6}

Previously, IL-6 was classified as a proinflammatory cytokine. Therefore, IL- 6 was thought to be induced through exercise and was closely related to muscle damage (Bruunsgaard, 1997). Recently, however, it was shown that IL-6 is produced by muscle cells IL-6 in human myoblasts (Bartoccioni et al., 1994; De Rossi et al., 2000) and human cultured myotubes (Keller et al., 2006). IL-6 was also observed in growing murine myofibers and satellite cells (Serrano et al., 2008). The systemic level of IL-6 in the circulation increases markedly with systemic exercise. Muscle contractions lead to the production and release of IL6 into the circulation. The increase in circulating IL-6 with exercise has a number of biological effects, including increased glucose uptake into muscle and insulin-induced glucose accumulation, as well as lipolysis and fat oxidation in fat metabolism. In addition, IL-6 has a role in myogenesis and mediates anti-inflammatory effects. Interestingly, IL-6 stimulates intestine $\mathrm{L}$ cells and pancreas $\alpha$ cells, and increases the secretion of glucagon-like peptide-1 (GLP-1), improving insulin secretion in pancreas $\beta$ cells (Ellingsgaard et al., 2011). Muscle-induced IL-6 circulates systemically, interacts with the pancreas, and may regulate glucose metabolism. Glycogen intake by myocytes and the accumulation of glycogen in myocytes induced by insulin in animal should be further examined.

\section{Brain-derived neurotropic factor}

Brain-derived neurotropic factor (BDNF) is a neurotrophin that exerts numerous effects on neurons primarily through Trk receptor tyrosine kinases. Although BNDF was thought to be a neuron-related factor, induction of BNDF expression in the muscle was observed following both exercise and electrical stimulation (and contraction) of skeletal muscle (Seidl et al., 1998; Copray et al., 2000; Gómez-Pinilla et al., 2002; Matthews et al., 2009).

Active muscle contraction modulates BDNF levels in the muscle. BDNF appears to play a role in the development and differentiation of myoblasts and muscle fibers (Mousavi and Jasmin, 2006; Miura et al., 2012). Interestingly, BDNF increased the phosphorylation of AMPK and ACC and enhanced fat oxidation both in vitro and ex vivo. BDNF is increased by contraction to enhance fat oxidation in an AMPK-dependent fashion, which is thought to occur in an autocrine and/or paracrine manner within skeletal muscle (Pedersen, 2009, 2011; Pedersen et al., 2009). Moreover, muscle-derived BDNF has an important role in muscle repair, regeneration, and differentiation. Thus, though BDNF is famous for its role in neurobiology, it can be identified as a myokine with a role in peripheral metabolism such as fat oxidation, myogenesis, and muscle regeneration. 


\section{Irisin}

Irisin, a transmembrane protein fibronectin type III domain containing 5 (FNDC5), was recently identified as a myokine. Irisin was identified when PGC1 $\alpha$ was overexpressed in the muscles of mice. Irisin stimulates brown white adipocytes, contributes to the loss of body weight, and improves glucose metabolism. Irisin is regulated by exercise and plays a role in driving white fat cells into "brite" cells with a brown-fat-like phenotype (Boström et al., 2012). Recently, bovine FNDC5 was identified and compared in mice and humans (Komolka et al., 2014). Although similarly organized in the human and murine loci, higher variability was observed at the transcript level in the bovine locus, and FNDC5 mRNA was abundant in bovine skeletal muscle and detected at lower levels in adipose tissue and the liver, not in circulation, although FNDC5 was observed in both skeletal muscle and circulation in murine. They also reported fundamental differences in the regulation of FNDC5 and Irisin between rodents and cattle. These differences should be further examined in livestock studies.

\section{Hepatocyte growth factor}

Among all growth factors studied, including fibroblast growth factors (FGFs), IGF-1, platelet-derived growth factor $\mathrm{BB}$ (PDGF-BB), transforming growth factor- $\beta$ s (TGF- $\beta 1$ and 2 ), and epidermal growth factor (EGF), hepatocyte growth factor (HGF) is the only mitogen that has been demonstrated to stimulate quiescent satellite cells to enter the cell cycle early in primary culture assay and in vivo (Allen et al., 1995; Tatsumi et al., 1998; Charge and Rudnicki, 2004; Wozniak et al., 2005; Martins et al., 2011). HGF is a heparin-binding protein localized in the extracellular domain of un-injured skeletal muscle fibers through a possible association with the glycosaminoglycan chains of proteoglycans, and its predominant form is the active disulfide-linked heterodimer of a $60-\mathrm{kDa} \alpha$-chain and a $30-\mathrm{kDa} \beta$-chain (Tatsumi and Allen, 2004). The intracellular signaling receptor for HGF is the c-met proto-oncogene; its message and protein have been observed in quiescent and activated satellite cells. Thus, the release of $\mathrm{HGF}$ from its sequestration in the matrix and subsequent presentation to the receptor c-met may be a critical aspect of the activation of quiescent satellite cells (Tatsumi et al., 2001; Tatsumi et al., 2002; Tatsumi et al., 2006; Yamada et al., 2006; Tatsumi and Allen, 2008; Yamada et al., 2008; Tatsumi et al., 2009; Tatsumi, 2010). Recently, Wozniak and Anderson (2005) showed that HGF released from the matrix may induce c-met RNA expression as an immediate-early gene within $30 \mathrm{~min}$ in response to muscle fiber stretch, thus enhancing HGF-c-met signaling during the satellite-cell activation process (Wozniak and Anderson, 2007). Yamada et al. (2010) proposed an additional role of HGF in quiescence through a negative feedback mechanism following satellite cell activation and proliferation; high concentrations of HGF (over $10 \mathrm{ng} / \mathrm{mL}$ in culture media) were shown to stimulate the expression of myostatin (GDF11) through a pathway that does not involve c-met (Yamada et al., 2010). Considering that HGF is produced by proliferating satellite cells and in spleen and liver cells in response to muscle damage, local concentrations of HGF bathing satellite cells may reach a threshold to induce myostatin expression during muscle regeneration. This time-lag may delay the action of the quiescence signaling program in proliferating satellite cells during initial phases of regeneration followed by induction of quiescence in a subset of cells during later phases.

\section{Semaphorin 3A}

Recently Tatsumi et al. found that satellite cells, resident myogenic stem cells normally positioned beneath the basal lamina of mature muscle fibers, produce and secrete a large amount of a multi-functional modulator semaphorin 3A (Sema3A) (a class 3 vertebrate-secreted semaphorin originally identified as a neural chemorepellent, also referred to as Sema3, SemD, and collapsing) exclusively during the early-differentiation phase in response to in vivo injury by crush or cardiotoxin-injection of the gastrocnemius muscle in the adult rat and mouse lower hind-limbs. Subsequent experiments also demonstrated that Sema3A up-regulation is induced by in vitro $\mathrm{HGF} / \mathrm{FGF} 2$ treatments of primary cultures of satellite cells (Tatsumi et al., 2009; Do et al., 2011; Sato et al., 2013; Shono et al., 2013; Sakaguchi et al., 2014; Sawano et al., 2014). Additionally, emerging evidence has shown that satellite cell cultures prepared from adult rat soleus muscle (slow-fiber abundant) secrete more Sema3A than those from the fast-twitch extensor digitorum longus muscle upon growth factor treatment (Suzuki et al., 2013), indicating that the Sema3A secretion burst mediates the early myogenic differentiation of satellite cell-derived myoblasts and/or fiber-type regulation of the newly-formed myofibers during muscle regeneration following injury. The physiological significance of the Sema3A burst remains unclear, and further studies are needed to examine the assumed implication in regenerative myogenesis and motoneuritogenesis, including neurite sprouting and reattachment of motoneuron terminals onto damaged and generated muscle fibers.

\section{Other myokines}

Interleukin-7 is a cytokine that is required for $\mathrm{T}$ and $\mathrm{B}$ cell development related to the immune system. IL-7 functions as a myokine in nonimmune cells (Haugen et al., 2010). IL-7 expression may be involved in myogenesis and its expression in resting skeletal muscle is increased with training adaptation.

Interleukin-8 belongs to the $\mathrm{CXC}$ family of chemokines (Baggiolini, 2001). It has been reported that IL-8 and CXCL- 


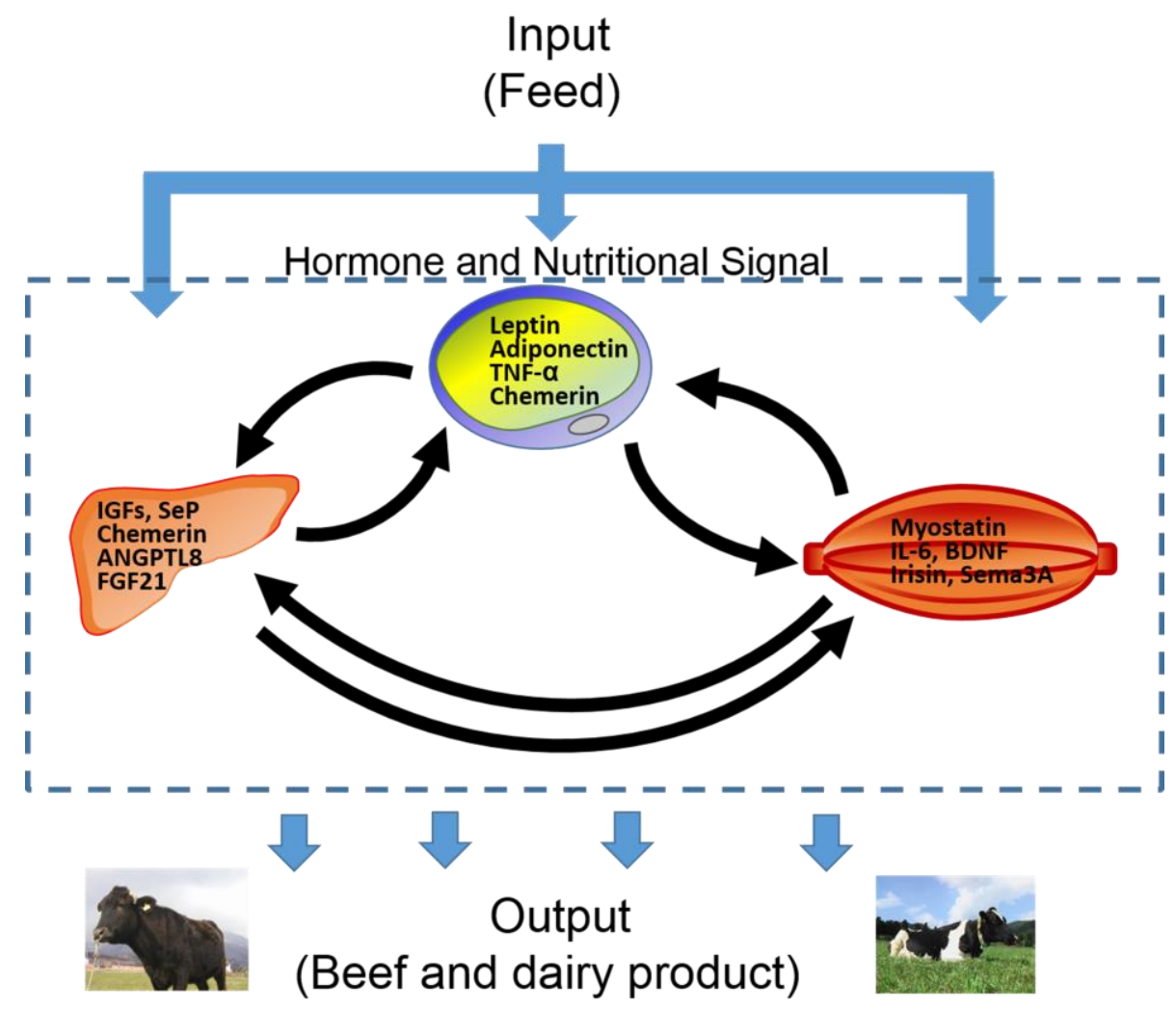

Figure 3. Endocrine crosstalk of adipokines, hepatokines, and myokines in ruminants. TNF- $\alpha$, tumor necrosis factor- $\alpha$; IGFs, insulin like growth factors; ANGPTL8, angiopoietin-like protein 8; FGF21, fibroblast growth factor 21; IL-6, interleukin-6; BDNF, brain-derived neurotropic factor; HGF, hepatocyte growth factor; Sema3A, semaphorin 3A.

1 (CXC Ligand 1) are increased in contracting skeletal muscle and that IL-8 is released from human muscle cells in vitro (Nieman et al., 2003). However, a more likely function of muscle-derived IL-8 is the stimulation of angiogenesis in skeletal muscle (Pedersen, 2013).

Interleukin-15 was originally isolated based on its ability to support natural killer T-lymphocyte proliferation. The IL15 transcript is expressed in a variety of nonlymphoid tissues, with particularly high expression in the skeletal muscle and placenta (Pedersen, 2013). The regulatory role of IL-15 in muscle contraction remains unclear. It is thought that IL-15 plays a role muscle-fat cross-talk because IL-15 has been identified as an anabolic factor that is highly expressed in skeletal muscle (Grabstein et al., 1994). Muscle-derived IL15 should be classified as a potential myokine.

Leukemia inhibitory factor (LIF), which was originally identified in 1988 as a protein secreted from ascites tumor cells (Hilton et al., 1988), was recently found to be a myokine. It is thought that LIF is induced in skeletal muscle following exercise and affects satellite cells, muscle growth, and regeneration (Pedersen, 2013).

$\beta$-aminoisobutyric acid (BAIBA) stimulates white adipocytes to promote gene expression, particularly in brown adipocytes. BAIBA promotes the expression of PPAR $\alpha$ and enhances fat oxidation (Roberts et al., 2014).

In summary, myokines function in the following: i) muscle hypertrophy or regeneration (myostatin, LIF, LI-4, IL-6, IL-7, IL-15, and Sem3A), ii) adipose tissue oxidation (IL-6 and BDNF), iii) insulin sensitivity (IL-6), iv) osteogenesis (IGF-I, FGF-2), v) anti-inflammation (IL-6), and 6) antitumor defense (unidentified secreted factors) and pancreas function (unidentified secreted factor) (Pedersen, 2013). In the future, myokine studies should be conducted to identify the cause of sarcopenia and to develop related biomarkers and medicines. Moreover, in the livestock science field, myokine research may result in the development of novel markers related to growth performance as well as muscle development and meat quality.

\section{CONCLUSION}

Taken together, hormones and nutrition signals affect feed control and the cross-talk between the adipose, liver, and muscle tissues in the beef and dairy products of ruminants (Figure 3). Determining the molecular mechanism and physiological system for feeding and energy metabolism in ruminants is essential for improving productivity and animal health. In this review, we summarized the current literature 
Table 1. Summary of physiological roles of adipokines, hepatokines and myokines in ruminants

\begin{tabular}{lll}
\hline & & \multicolumn{1}{c}{ Physiological roles } \\
\hline Adipokines & Adiponectin & $\begin{array}{l}\text { Correlated with BCS and carcass composition } \\
\text { Decreased the GH secretion } \\
\text { Increased after parturition }\end{array}$ \\
& TNF- $\alpha$ & $\begin{array}{l}\text { Increased gene expression of adipose tissue in lactating cows } \\
\text { Increased TG } \\
\text { Increased lipolysis }\end{array}$ \\
Chemerin & Increased insulin secretion \\
Hepatokines & IGFs & Increased milk production \\
& Correlated with growth \\
& Selenoprotein P & Increased gene expression by insulin \\
& Decreased in the liver of post-weaning calves \\
& ANGPTL8 & Decreased the gene expression by insulin and propionate \\
FGF21 & Decreased after parturition \\
IL-6 & Increased after parturition \\
& Adipose tissue oxidation \\
& BDNF & Anti-inflammation \\
Irisin & Myogenesis \\
HGF & High expression in skeletal muscle \\
& Sema3A & Muscle regeneration \\
\hline
\end{tabular}

TNF- $\alpha$, tumor necrosis factor- $\alpha$; IGFs, insulin like growth factors; ANGPTL8, angiopoietin-like protein 8; FGF21, fibroblast growth factor 21; IL-6, interleukin- 6; BDNF, brain-derived neurotropic factor; HGF, hepatocyte growth factor; Sema3A, semaphorin 3A.

regarding about several cytokines secreted form adipose tissue, liver tissue, and muscle tissues (Table 1). Additional studies examining the metabolism and endocrine network will contribute to animal production in terms of both quantity and quality in ruminant.

\section{CONFLICT OF INTEREST}

We certify that there is no conflict of interest with any financial organization regarding the material discussed in the manuscript.

\section{ACKNOWLEDGMENTS}

This work was supported by JSPS KAKENHI Grant Number 25292158, 25292163.

\section{REFERENCES}

Aggarwal, B. B. 2003. Signalling pathways of the TNF superfamily: A double-edged sword. Nat. Rev. Immunol 3: 745-756.

Allen, R. E., S. M. Sheehan, R. G. Taylor, T. L. Kendall, and G. M. Rice. 1995. Hepatocyte growth factor activates quiescent skeletal muscle satellite cells in vitro. J Cell Physiol. 165:307312 .

Auberger, P., L. Falquerho, J. O. Contreres, G. Pages, G. Le Cam, B. Rossi, and A. Le Cam. 1989. Characterization of a natural inhibitor of the insulin receptor tyrosine kinase: cDNA cloning, purification, and anti-mitogenic activity. Cell 58:631-640.

Baggiolini, M. 2001. Chemokines in pathology and medicine. J. Int.
Med. 250:91-104.

Baik, M., T. T. Vu, M. Y. Piao, and H. J. Kang. 2014. Association of DNA methylation levels with tissue-specific expression of adipogenic and lipogenic genes in longissimus dorsi muscle of Korean cattle. Asian Australas. J. Anim. Sci. 27:1493-1498.

Bartoccioni, E., D. Michaelis, and R. Hohlfeld. 1994. Constitutive and cytokine-induced production of interleukin- 6 by human myoblasts. Immunol. Lett. 42:135-138.

Belk, K. E., J. D. Tatum, and F. L. Williams, Jr. 1991. Deposition and distribution of carcass fat for steers differing in frame size and muscle thickness. J. Anim. Sci. 69:609-616.

Bell, A. W. 1995. Regulation of organic nutrient metabolism during transition from late pregnancy to early lactation. J. Anim. Sci. 73:2804-2819.

Berg, A. H., T. P. Combs, X. Du, M. Brownlee, and P. E. Scherer. 2001. The adipocyte-secreted protein Acrp30 enhances hepatic insulin action. Nat. Med. 7:947-953.

Bishop, M. D., R. C. M. Simmen, F. A. Simmen, and M. E. Davis. 1989. The relationship of insulin-like growth factor-I with postweaning performance in Angus beef cattle. J. Anim. Sci. 67: 2872-2880.

Bobe, G., J. W. Young, and D. C. Beitz. 2004. Invited review: Pathology, etiology, prevention, and treatment of fatty liver in dairy cows. J. Dairy Sci. 87:3105-3124.

Boström, P., J. Wu, M. P. Jedrychowski, A. Korde, L. Ye, J. C. Lo, K. A. Rasbach, E. A. Boström, J. H. Choi, and J. Z. Long et al. 2012. A PGC1-[agr]-dependent myokine that drives brown-fatlike development of white fat and thermogenesis. Nature 481: 463-468.

Bozaoglu, K., K. Bolton, J. McMillan, P. Zimmet, J. Jowett, G. Collier, K. Walder, and D. Segal. 2007. Chemerin is a novel adipokine associated with obesity and metabolic syndrome. 
Endocrinology 148:4687-4694.

Bozaoglu, K., D. Segal, K. A. Shields, N. Cummings, J. E. Curran, A. G. Comuzzie, M. C. Mahaney, D. L. Rainwater, J. L. VandeBerg, J. W. MacCluer, G. Collier, J. Blangero, K. Walder, and J. B. Jowett. 2009. Chemerin is associated with metabolic syndrome phenotypes in a Mexican-American population. J. Clin. Endocrinol. Metab. 94:3085-3088.

Brakenhielm, E., R. Cao, B. Gao, B. Angelin, B. Cannon, P. Parini, and Y. Cao. 2004. Angiogenesis inhibitor, TNP-470, prevents diet-induced and genetic obesity in mice. Circ. Res. 94:15791588.

Bruun, J. M., S. B. Pedersen, K. Kristensen, and B. Richelsen. 2002. Effects of pro-inflammatory cytokines and chemokines on leptin production in human adipose tissue in vitro. Mol. Cell. Endocrinol. 190:91-99.

Bruunsgaard, H. 1997. Exercise-induced increase in interleukin-6 is related to muscle damage. J. Physiol.(Lond) 499(Pt 3):833-841.

Bub, J. D., T. Miyazaki, and Y. Iwamoto. 2006. Adiponectin as a growth inhibitor in prostate cancer cells. Biochem. Biophys. Res. Commun. 340:1158-1166.

Burk, R. F. and K. E. Hill. 2005. Selenoprotein P: An extracellular protein with unique physical characteristics and a role in selenium homeostasis. Annu. Rev. Nutr. 25:215-235.

Carlson, B. A., S. V. Novoselov, E. Kumaraswamy, B. J. Lee, M. R. Anver, V. N. Gladyshev, and D. L. Hatfield. 2004. Specific excision of the selenocysteine tRNA[Ser]Sec (Trsp) gene in mouse liver demonstrates an essential role of selenoproteins in liver function. J. Biol. Chem. 279:8011-8017.

Cawthorn, W. P. and J. K. Sethi. 2008. TNF-alpha and adipocyte biology. FEBS Lett. 582:117-131.

Charge, S. B. and M. A. Rudnicki. 2004. Cellular and molecular regulation of muscle regeneration. Physiol. Rev. 84:209-238.

Choi, S. H., S. K. Park, B. J. Johnson, K. Y. Chung, C. W. Choi, K. H. Kim, W. Y. Kim, and B. Smith. 2015. AMPKalpha, C/EBPbeta, CPT1beta, GPR43, PPARgamma, and SCD gene expression in single- and co-cultured bovine satellite cells and intramuscular preadipocytes treated with palmitic, stearic, oleic, and linoleic acid. Asian Australas. J. Anim. Sci. 28:411-419.

Copray, S., R. Liem, N. Brouwer, P. Greenhaff, F. Habens, and P. Fernyhough. 2000. Contraction-induced muscle fiber damage is increased in soleus muscle of streptozotocin-diabetic rats and is associated with elevated expression of brain-derived neurotrophic factor mRNA in muscle fibers and activated satellite cells. Exp. Neurol. 161:597-608.

Cox, A. R., C. J. Lam, C. W. Bonnyman, J. Chavez, J. S. Rios, and J. A. Kushner. 2015. Angiopoietin-like protein 8 (ANGPTL8)/betatrophin overexpression does not increase beta cell proliferation in mice. Diabetologia 58:1523-1531.

Daniel, J. A., T. H. Elsasser, C. D. Morrison, D. H. Keisler, B. K. Whitlock, B. Steele, D. Pugh, and J. L. Sartin. 2003. Leptin, tumor necrosis factor-alpha (TNF), and CD14 in ovine adipose tissue and changes in circulating TNF in lean and fat sheep. J. Anim. Sci. 81:2590-2599.

De Cesaris, P., D. Starace, A. Riccioli, F. Padula, A. Filippini, and E. Ziparo. 1998. Tumor necrosis factor-alpha induces interleukin-6 production and integrin ligand expression by distinct transduction pathways. J. Biol. Chem. 273:7566-7571.

De Rossi, M., P. Bernasconi, F. Baggi, R. De Waal Malefyt, and R.
Mantegazza. 2000. Cytokines and chemokines are both expressed by human myoblasts: possible relevance for the immune pathogenesis of muscle inflammation. Int. Immunol. 12:1329-1335.

Delavaud, C., F. Bocquier, Y. Chilliard, D. H. Keisler, A. Gertler, and G. Kann. 2000. Plasma leptin determination in ruminants: effect of nutritional status and body fatness on plasma leptin concentration assessed by a specific RIA in sheep. J Endocrinol. 165:519-526

Deng, Y., H. Wang, Y. Lu, S. Liu, Q. Zhang, J. Huang, R. Zhu, J. Yang, R. Zhang, D. Zhang, W. Shen, G. Ning, and Y. Yang. 2013. Identification of chemerin as a novel FXR target gene downregulated in the progression of nonalcoholic steatohepatitis. Endocrinology 154:1794-1801.

Do, M.-K. Q., Y. Sato, N. Shimizu, T. Suzuki, J. Shono, W. Mizunoya, M. Nakamura, Y. Ikeuchi, J. E. Anderson, and R. Tatsumi. 2011. Growth factor regulation of neural chemorepellent Sema3A expression in satellite cell cultures. Am. J. Physiol. Cell Physiol. 301:C1270-C1279.

Docke, S., J. F. Lock, A. L. Birkenfeld, S. Hoppe, S. Lieske, A. Rieger, N. Raschzok, I. M. Sauer, S. Florian, and M. A. Osterhoff et al. 2013. Elevated hepatic chemerin mRNA expression in human non-alcoholic fatty liver disease. Eur. J. Endocrinol. 169:547-557.

Doroudgar, S. and C. C. Glembotski. 2011. The cardiokine story unfolds: Ischemic stress-induced protein secretion in the heart. Trends Mol. Med. 17:207-214.

Drackley, J. K., T. R. Overton, and G. N. Douglas. 2001. Adaptations of glucose and long-chain fatty acid metabolism in liver of dairy cows during the periparturient period. J. Dairy Sci. 84:E100-E112.

Ellingsgaard, H., I. Hauselmann, B. Schuler, A. M. Habib, L. L. Baggio, D. T. Meier, E. Eppler, K. Bouzakri, S. Wueest, and Y. D. Muller et al. 2011. Interleukin-6 enhances insulin secretion by increasing glucagon-like peptide-1 secretion from L cells and alpha cells. Nat. Med. 17:1481-1489.

Fawcett, R. L., A. S. Waechter, L. B. Williams, P. Zhang, R. Louie, R. Jones, M. Inman, J. Huse, and R. V. Considine. 2000. Tumor necrosis factor-alpha inhibits leptin production in subcutaneous and omental adipocytes from morbidly obese humans. J. Clin. Endocrinol. Metab. 85:530-535.

Feuermann, Y., S. J. Mabjeesh, L. Niv-Spector, D. Levin, and A. Shamay. 2006. Prolactin affects leptin action in the bovine mammary gland via the mammary fat pad. J Endocrinol 191: 407-413.

Fruebis, J., T. S. Tsao, S. Javorschi, D. Ebbets-Reed, M. R. Erickson, F. T. Yen, B. E. Bihain, and H. F. Lodish. 2001. Proteolytic cleavage product of $30-\mathrm{kDa}$ adipocyte complement-related protein increases fatty acid oxidation in muscle and causes weight loss in mice. Proc. Natl. Acad. Sci. USA. 98:2005-2010.

Gómez-Pinilla, F., Z. Ying, R. R. Roy, R. Molteni, and V. R. Edgerton. 2002. Voluntary exercise induces a BDNF-mediated mechanism that promotes neuroplasticity. J. Neurophysiol. 88: 2187-2195.

Geary, T. W., E. L. McFadin, M. D. MacNeil, E. E. Grings, R. E. Short, R. N. Funston, and D. H. Keisler. 2003. Leptin as a predictor of carcass composition in beef cattle. J. Anim. Sci. $81: 1-8$. 
Goff, J. P. and J. R. Stabel. 1990. Decreased plasma retinol, alphatocopherol, and zinc concentration during the periparturient period: effect of milk fever. J. Dairy Sci. 73:3195-3199.

Goralski, K. B., T. C. McCarthy, E. A. Hanniman, B. A. Zabel, E. C. Butcher, S. D. Parlee, S. Muruganandan, and C. J. Sinal. 2007. Chemerin, a novel adipokine that regulates adipogenesis and adipocyte metabolism. J. Biol. Chem. 282:28175-28188.

Gotoh, T. 2003. Histochemical properties of skeletal muscles in Japanese cattle and their meat production ability. Anim. Sci. J. 74:339-354.

Gotoh, T., H. Iwamoto, Y. Nakanishi, R. Umetsu, and Y. Ono. 1999. Histochemical properties of skeletal muscles in different body parts of young Japanese black steers. Anim. Sci. Technol. 70:497-509.

Grabstein, K. H., J. Eisenman, K. Shanebeck, C. Rauch, S. Srinivasan, V. Fung, C. Beers, J. Richardson, M. A. Schoenborn, and M. Ahdieh et al. 1994. Cloning of a T cell growth factor that interacts with the beta chain of the interleukin-2 receptor. Science 264:965-968.

Gusarova, V., C. A. Alexa, E. Na, P. E. Stevis, Y. Xin, S. BonnerWeir, J. C. Cohen, H. H. Hobbs, A. J. Murphy, G. D. Yancopoulos, and J. Gromada. 2014. ANGPTL8/betatrophin does not control pancreatic beta cell expansion. Cell 159:691696.

Haugen, F., F. Norheim, H. Lian, A. J. Wensaas, S. Dueland, O. Berg, A. Funderud, B. S. Skålhegg, T. Raastad, and C. A. Drevon. 2010. IL-7 is expressed and secreted by human skeletal muscle cells. Am. J. Physiol.-Cell Physiol. 298:C807-C816.

Hilton, D. J., N. A. Nicola, and D. Metcalf. 1988. Purification of a murine leukemia inhibitory factor from Krebs ascites cells. Anal. Biochem. 173: 359-367.

Hu, W. and P. Feng. 2011. Elevated serum chemerin concentrations are associated with renal dysfunction in type 2 diabetic patients. Diabetes Res. Clin. Pract. 91:159-163.

Kadokawa, H., J. R. Briegel, M. A. Blackberry, D. Blache, G. B. Martin, and N. R. Adams. 2003. Relationships between plasma concentrations of leptin and other metabolic hormones in GHtransgenic sheep infused with glucose. Domest. Anim. Endocrinol. 24:219-229.

Kang, H. J., N. H. Trang, and M. Baik. 2015. Effects of dietary restriction on the expression of lipid metabolism and growth hormone signaling genes in the longissimus dorsi muscle of Korean cattle steers. Asian Australas. J. Anim. Sci. 28:11871193.

Keller, C., Y. Hellsten, A. Steensberg, and B. K. Pedersen. 2006. Differential regulation of IL-6 and TNF-alpha via calcineurin in human skeletal muscle cells. Cytokine 36:141-147.

Kenison, D. C., T. H. Elsasser, and R. Fayer. 1991. Tumor necrosis factor as a potential mediator of acute metabolic and hormonal responses to endotoxemia in calves. Am. J. Vet. Res. 52:13201326.

Kokkonen, T., J. Taponen, T. Anttila, L. Syrjala-Qvist, C. Delavaud, Y. Chilliard, M. Tuori, and A. T. Tesfa. 2005. Effect of body fatness and glucogenic supplement on lipid and protein mobilization and plasma leptin in dairy cows. J. Dairy Sci. 88:1127-1141.

Komatsu, T., F. Itoh, S. Mikawa, and K. Hodate. 2003. Gene expression of resistin in adipose tissue and mammary gland of lactating and non-lactating cows. J. Endocrinol. 178:R1-R5.

Komatsu, T., F. Itoh, R. Sakumoto, K. Hodate, Y. Obara, and S. Kushibiki. 2007. Changes in the gene expression of adiponectin and glucose transporter 12 (GLUT12) in lactating and nonlactating cows. Anim. Sci. J. 78:98-102.

Komolka, K., E. Albrecht, L. Schering, J. Brenmoehl, A. Hoeflich, and S. Maak. 2014. Locus characterization and gene expression of bovine FNDC5: Is the myokine irisin relevant in cattle? PLoS One 9:e88060.

Krautbauer, S., J. Wanninger, K. Eisinger, Y. Hader, M. Beck, A. Kopp, A. Schmid, T. S. Weiss, C. Dorn, and C. Buechler. 2013. Chemerin is highly expressed in hepatocytes and is induced in non-alcoholic steatohepatitis liver. Exp. Mol. Pathol. 95:199205.

Kushibiki, S., K. Hodate, H. Shingu, Y. Ueda, Y. Mori, T. Itoh, and Y. Yokomizo. 2001a. Effects of long-term administration of recombinant bovine tumor necrosis factor-alpha on glucose metabolism and growth hormone secretion in steers. Am. J. Vet. Res. 62:794-798.

Kushibiki, S., K. Hodate, H. Shingu, Y. Ueda, M. Shinoda, Y. Mori, T. Itoh, and Y. Yokomizo. 2001b. Insulin resistance induced in dairy steers by tumor necrosis factor alpha is partially reversed by 2,4-thiazolidinedione. Domest. Anim. Endocrinol. 21:25-37.

Kushibiki, S., K. Hodate, Y. Ueda, H. Shingu, Y. Mori, T. Itoh, and Y. Yokomizo. 2000. Administration of recombinant bovine tumor necrosis factor-alpha affects intermediary metabolism and insulin and growth hormone secretion in dairy heifers. J. Anim. Sci. 78:2164-2171.

Laliotis, G. P., I. Bizelis, and E. Rogdakis. 2010. Comparative Approach of the de novo Fatty Acid Synthesis (Lipogenesis) between Ruminant and Non Ruminant Mammalian Species: From Biochemical Level to the Main Regulatory Lipogenic Genes. Curr. Genomics 11:168-183.

Lee, H. G., Y. J. Choi, S. R. Lee, H. Kuwayama, H. Hidari, and S. K. You. 2005a. Effects of dietary protein and growth hormonereleasing peptide (GHRP-2) on plasma IGF-1 and IGFBPs in Holstein steers. Domest. Anim. Endocrinol. 28:134-146.

Lee, H. G., H. Hidari, S. K. Kang, Z. S. Hong, C. X. Xu, S. H. Kim, K. S. Seo, D. H. Yoon, and Y. J. Choi. 2005b. The Relationships between plasma insulin-like growth factor (IGF)-1 and IGFbinding proteins (IGFBPs) to growth pattern, and characteristics of plasma IGFBPs in steers. Asian Australas. J. Anim. Sci. 18:1575-1581.

Lents, C. A., R. P. Wettemann, F. J. White, I. Rubio, N. H. Ciccioli, L. J. Spicer, D. H. Keisler, and M. E. Payton. 2005. Influence of nutrient intake and body fat on concentrations of insulin-like growth factor-I, insulin, thyroxine, and leptin in plasma of gestating beef cows. J. Anim. Sci. 83:586-596.

Luo, X. H., L. J. Guo, L. Q. Yuan, H. Xie, H. D. Zhou, X. P. Wu, and E. Y. Liao. 2005. Adiponectin stimulates human osteoblasts proliferation and differentiation via the MAPK signaling pathway. Exp. Cell Res. 309:99-109.

Martins, K. J., I. MacLean, G. K. Murdoch, W. T. Dixon, and C. T. Putman. 2011. Nitric oxide synthase inhibition delays lowfrequency stimulation-induced satellite cell activation in rat fast-twitch muscle. Appl. Physiol. Nutr. Metab. 36:996-1000.

Matsumoto, K., S. Hashimoto, Y. Gon, T. Nakayama, and T. Horie. 1998. Proinflammatory cytokine-induced and chemical 
mediator-induced IL-8 expression in human bronchial epithelial cells through p38 mitogen-activated protein kinase-dependent pathway. J. Allergy Clin. Immunol. 101:825-831.

Matthews, V., M.-B. Åström, M. H. S. Chan, C. R. Bruce, K. S. Krabbe, O. Prelovsek, T. Åkerström, C. Yfanti, C. Broholm, and O. Mortensen et al. 2009. Brain-derived neurotrophic factor is produced by skeletal muscle cells in response to contraction and enhances fat oxidation via activation of AMP-activated protein kinase. Diabetologia 52:1409-1418.

McCann, J. P., S. C. Loo, D. L. Aalseth, and T. Abribat. 1997. Differential effects of GH stimulation on fasting and prandial metabolism and plasma IGFs and IGF-binding proteins in lean and obese sheep. J. Endocrinol. 154:329-346.

Memon, R. A., K. R. Feingold, A. H. Moser, J. Fuller, and C. Grunfeld. 1998. Regulation of fatty acid transport protein and fatty acid translocase mRNA levels by endotoxin and cytokines. Am. J. Physiol. - Endocrinol. Metab. 274:E210-E217.

Misu, H., T. Takamura, H. Takayama, H. Hayashi, N. MatsuzawaNagata, S. Kurita, K. Ishikura, H. Ando, Y. Takeshita, and T. Ota et al. 2010. A liver-derived secretory protein, selenoprotein P, causes insulin resistance. Cell Metab. 12:483-495.

Miura, P., A. Amirouche, C. Clow, G. Bélanger, and B. J. Jasmin. 2012. Brain-derived neurotrophic factor expression is repressed during myogenic differentiation by miR-206. J. Neurochem. 120:230-238.

Morrison, C. D., J. A. Daniel, B. J. Holmberg, J. Djiane, N. Raver, A. Gertler, and D. H. Keisler. 2001. Central infusion of leptin into well-fed and undernourished ewe lambs: effects on feed intake and serum concentrations of growth hormone and luteinizing hormone. J. Endocrinol. 168:317-324.

Mousavi, K. and B. J. Jasmin. 2006. BDNF is expressed in skeletal muscle satellite cells and inhibits myogenic differentiation. J. Neurosci. 26:5739-5749.

Murata, Y., M. Konishi, and N. Itoh. 2011. FGF21 as an Endocrine Regulator in Lipid Metabolism: From Molecular Evolution to Physiology and Pathophysiology. J. Nutr. Metab. Article ID 981315.

Nicola, N. 1994. Guidebook to Cytokines and Their Receptors. Oxford Univ. Press, Oxford, UK.

Nieman, D. C., J. M. Davis, D. A. Henson, J. Walberg-Rankin, M. Shute, C. L. Dumke, A. C. Utter, D. M. Vinci, J. A. Carson, and A. Brown. 2003. Carbohydrate ingestion influences skeletal muscle cytokine mRNA and plasma cytokine levels after a 3-h run. J. Appl. Physiol. 94:1917-1925.

Ohtani, Y., T. Takahashi, K. Sato, A. Ardiyanti, S. H. Song, R. Sato, K. Onda, Y. Wada, Y. Obara, K. Suzuki, A. Hagino, S. G. Roh, and K. Katoh. 2012. Changes in circulating adiponectin and metabolic hormone concentrations during periparturient and lactation periods in Holstein dairy cows. Anim. Sci. J. 83:788795.

Ohtani, Y., T. Yonezawa, S. H. Song, T. Takahashi, A. Ardiyanti, K. Sato, A. Hagino, S. G. Roh, and K. Katoh. 2011. Gene expression and hormonal regulation of adiponectin and its receptors in bovine mammary gland and mammary epithelial cells. Anim. Sci. J. 82:99-106.

Oike, Y., M. Akao, K. Yasunaga, T. Yamauchi, T. Morisada, Y. Ito, T. Urano, Y. Kimura, Y. Kubota, and H. Maekawa, et al. 2005. Angiopoietin-related growth factor antagonizes obesity and insulin resistance. Nat. Med. 11:400-408.

Pedersen, B. K. 2009. The diseasome of physical inactivity-and the role of myokines in muscle-fat cross talk. J. Physiol. 587: 55595568.

Pedersen, B. K. 2011. Exercise-induced myokines and their role in chronic diseases. Brain Behav. Immun. 25:811-816.

Pedersen, B. K. 2013. Muscle as a secretory organ. Compr. Physiol. 3:1337-1362.

Pedersen, B. K., T. C. Akerstrom, A. R. Nielsen, and C. P. Fischer. 2007. Role of myokines in exercise and metabolism. J. Appl. Physiol. 103:1093-1098.

Pedersen, B. K., M. Pedersen, K. S. Krabbe, H. Bruunsgaard, V. B. Matthews, and M. A. Febbraio. 2009. Role of exercise-induced brain-derived neurotrophic factor production in the regulation of energy homeostasis in mammals. Exp. Physiol. 94:1153-1160.

Pethick, D. W. and D. B. Lindsay. 1982. Metabolism of ketone bodies in pregnant sheep. Br. J. Nutr. 48:549-563.

Roberts, C. A., S. N. McCutcheon, H. T. Blair, P. D. Gluckman, and B. H. Breier. 1990. Developmental patterns of plasma insulinlike growth factor-1 concentrations in sheep. Domest. Anim. Endocrinol. 7:457-463.

Roberts, L. D., P. Boström, J. F. O'Sullivan, R. T. Schinzel, G. D. Lewis, A. Dejam, Y.-K. Lee, M. J. Palma, S. Calhoun, and A. Georgiadi. 2014. $\beta$-Aminoisobutyric acid induces browning of white fat and hepatic $\beta$-oxidation and is inversely correlated with cardiometabolic risk factors. Cell Metab. 19:96-108.

Roh, S., I. J. Clarke, R. W. Xu, J. W. Goding, K. Loneragan, and C. Chen. 1998. The in vitro effect of leptin on basal and growth hormone-releasing hormone-stimulated growth hormone secretion from the ovine pituitary gland. Neuroendocrinology 68:361-364.

Roh, S. G., D. Hishikawa, Y. H. Hong, and S. Sasaki. 2006. Control of adipogenesis in ruminants. Anim. Sci. J. 77:472-477.

Roh, S. G., G. Y. Nie, K. Loneragan, A. Gertler, and C. Chen. 2001. Direct modification of somatotrope function by long-term leptin treatment of primary cultured ovine pituitary cells. Endocrinology 142:5167-5171.

Roh, S. G., S. H. Song, K. C. Choi, K. Katoh, V. Wittamer, M. Parmentier, and S. Sasaki. 2007. Chemerin-A new adipokine that modulates adipogenesis via its own receptor. Biochem. Biophys. Res. Commun. 362:1013-1018.

Ronge, H. and J. Blum. 1989. Insulin-like growth factor I during growth in bulls. Reprod. Nutr. Dev. 29:105-111.

Ruan, H., P. D. Miles, C. M. Ladd, K. Ross, T. R. Golub, J. M. Olefsky, and H. F. Lodish. 2002. Profiling gene transcription in vivo reveals adipose tissue as an immediate target of tumor necrosis factor-alpha: implications for insulin resistance. Diabetes 51:3176-3188.

Ruan, H., M. J. Zarnowski, S. W. Cushman, and H. F. Lodish. 2003. Standard isolation of primary adipose cells from mouse epididymal fat pads induces inflammatory mediators and downregulates adipocyte genes. J. Biol. Chem. 278:47585-47593.

Saito, Y., T. Hayashi, A. Tanaka, Y. Watanabe, M. Suzuki, E. Saito, and K. Takahashi. 1999. Selenoprotein P in human plasma as an extracellular phospholipid hydroperoxide glutathione peroxidase. Isolation and enzymatic characterization of human selenoprotein p. J. Biol. Chem. 274:2866-2871.

Sakaguchi, S., J. Shono, T. Suzuki, S. Sawano, J. E. Anderson, M. 
K. Do, H. Ohtsubo, W. Mizunoya, Y. Sato, M. Nakamura, M. Furuse, K. Yamada, Y. Ikeuchi, and R. Tatsumi. 2014. Implication of anti-inflammatory macrophages in regenerative moto-neuritogenesis: promotion of myoblast migration and neural chemorepellent semaphorin $3 \mathrm{~A}$ expression in injured muscle. Int. J. Biochem. Cell Biol. 54:272-285.

Samitz, G., M. Egger, and M. Zwahlen. 2011. Domains of physical activity and all-cause mortality: systematic review and doseresponse meta-analysis of cohort studies. Int. J. Epidemiol. 40: $1382-1400$.

Sato, Y., M. K. Do, T. Suzuki, H. Ohtsubo, W. Mizunoya, M. Nakamura, M. Furuse, Y. Ikeuchi, and R. Tatsumi. 2013. Satellite cells produce neural chemorepellent semaphorin 3A upon muscle injury. Anim. Sci. J. 84:185-189.

Sawano, S., T. Suzuki, M. K. Do, H. Ohtsubo, W. Mizunoya, Y. Ikeuchi, and R. Tatsumi. 2014. Supplementary immunocytochemistry of hepatocyte growth factor production in activated macrophages early in muscle regeneration. Anim. Sci. J. 85:994-1000.

Scherer, P. E., S. Williams, M. Fogliano, G. Baldini, and H. F. Lodish. 1995. A novel serum protein similar to C1q, produced exclusively in adipocytes. J. Biol. Chem. 270:26746-26749.

Schoenberg, K. M., S. L. Giesy, K. J. Harvatine, M. R. Waldron, C. Cheng, A. Kharitonenkov, and Y. R. Boisclair. 2011. Plasma FGF21 is elevated by the intense lipid mobilization of lactation. Endocrinology 152:4652-4661.

Seidl, K., C. Erck, and A. Buchberger. 1998. Evidence for the participation of nerve growth factor and its low-affinity receptor (p75NTR) in the regulation of the myogenic program. J. Cell Physiol. 176:10-21.

Serrano, A. L., B. Baeza-Raja, E. Perdiguero, M. Jardí, and P. Muñoz-Cánoves. 2008. Interleukin-6 is an essential regulator of satellite cell-mediated skeletal muscle hypertrophy. Cell Metab. 7:33-44.

Shono, J. I., S. Sakaguchi, T. Suzuki, M. K. Q. Do, W. Mizunoya, M. Nakamura, Y. Sato, M. Furuse, K. Yamada, Y. Ikeuchi, and R. Tatsumi. 2013. Preliminary time-course study of antiinflammatory macrophage infiltration in crush-injured skeletal muscle. Anim. Sci. J. 84:744-750.

Soliman, M., K. Kimura, M. Ahmed, D. Yamaji, Y. Matsushita, Y. Okamatsu-Ogura, K. Makondo, and M. Saito. 2007. Inverse regulation of leptin mRNA expression by short- and long-chain fatty acids in cultured bovine adipocytes. Domest. Anim. Endocrinol. 33:400-409.

Song, S. H., K. Fukui, K. Nakajima, T. Kozakai, S. Sasaki, S. G. Roh, and K. Katoh. 2010. Cloning, expression analysis, and regulatory mechanisms of bovine chemerin and chemerin receptor. Domest. Anim. Endocrinol. 39:97-105.

Srinivas, P. R., A. S. Wagner, L. V. Reddy, D. D. Deutsch, M. A. Leon, A. S. Goustin, and G. Grunberger. 1993. Serum alpha 2HS-glycoprotein is an inhibitor of the human insulin receptor at the tyrosine kinase level. Mol. Endocrinol. 7:1445-1455.

Stanko, R. L., W. S. Cohick, D. W. Shaw, R. W. Harvey, D. R. Clemmons, M. D. Whitacre, and J. D. Armstrong. 1994. Effect of somatotropin and/or equine chorionic gonadotropin on serum and follicular insulin-like growth factor I and insulin-like growth factor binding proteins in cattle. Biol. Reprod. 50: 290300 .

Starace, D., R. Galli, A. Paone, P. De Cesaris, A. Filippini, E. Ziparo, and A. Riccioli. 2008. Toll-like receptor 3 activation induces antiviral immune responses in mouse sertoli cells. Biol. Reprod. 79:766-775.

Stefan, N. and H. U. Haring. 2013. The role of hepatokines in metabolism. Nat. Rev. Endocrinol. 9:144-152.

Suzuki, T., M. K. Do, Y. Sato, K. Ojima, M. Hara, W. Mizunoya, M. Nakamura, M. Furuse, Y. Ikeuchi, J. E. Anderson, and R. Tatsumi. 2013. Comparative analysis of semaphorin 3A in soleus and EDL muscle satellite cells in vitro toward understanding its role in modulating myogenin expression. Int. J. Biochem. Cell Biol. 45:476-482.

Suzuki, Y., Y. H. Hong, S. H. Song, A. Ardiyanti, D. Kato, K. H. So, K. Katoh, and S. G. Roh. 2012a. The regulation of chemerin and CMKLR1 genes expression by TNF- $\alpha$, adiponectin, and chemerin analog in bovine differentiated adipocytes. Asian Australas. J. Anim. Sci. 25:1316-1321.

Suzuki, Y., S. H. Song, K. Sato, K. H. So, A. Ardiyanti, S. Kitayama, Y. H. Hong, S. D. Lee, K. C. Choi, A. Hagino, K. Katoh, and S. G. Roh. 2012b. Chemerin analog regulates energy metabolism in sheep. Anim. Sci. J. 83:263-267.

Suzuki, Y., D. Kato, M. Kondo, H. Hatanaka, S. Haga, K. T. Gotoh, and S.G. Roh. 2015. Expressional regulation of chemerin and its receptors in the liver and adipose tissues of young cattle by weaning and nutrition. 2015 ADSA-ASAS Joint Annual Meeting. Orlando, FL, USA.

Suzuki, Y., S. Kitayama, M. Kondo, S. Haga, K. Katoh, and S. G. Roh. 2014. Chemerin mRNA Expression is regulated by insulin and fatty Acids in the liver of calves. Animal Production in Australia. Proceedings of the 30th Biennial Conference of the Australian. Canberra, Australia. 30:272.

Tatsumi, R. 2010. Mechano-biology of skeletal muscle hypertrophy and regeneration: Possible mechanism of stretch-induced activation of resident myogenic stem cells. Anim. Sci. J. 81:1120.

Tatsumi, R. and R. E. Allen. 2004. Active hepatocyte growth factor is present in skeletal muscle extracellular matrix. Muscle Nerve 30:654-658.

Tatsumi, R., and R. E. Allen. 2008. Mechano-biology of resident myogenic stem cells: Molecular mechanism of stretch-induced activation of satellite cells. Anim. Sci. J. 79:279-290.

Tatsumi, R., J. E. Anderson, C. J. Nevoret, O. Halevy, and R. E. Allen. 1998. HGF/SF is present in normal adult skeletal muscle and is capable of activating satellite cells. Dev. Biol. 194:114128.

Tatsumi, R., A. Hattori, Y. Ikeuchi, J. E. Anderson, and R. E. Allen. 2002. Release of hepatocyte growth factor from mechanically stretched skeletal muscle satellite cells and role of $\mathrm{pH}$ and nitric oxide. Mol. Biol. Cell 13:2909-2918.

Tatsumi, R., X. Liu, A. Pulido, M. Morales, T. Sakata, S. Dial, A. Hattori, Y. Ikeuchi, and R. E. Allen. 2006. Satellite cell activation in stretched skeletal muscle and the role of nitric oxide and hepatocyte growth factor. Am. J. Physiol. Cell Physiol. 290:C1487-C1494.

Tatsumi, R., Y. Sankoda, J. E. Anderson, Y. Sato, W. Mizunoya, N. Shimizu, T. Suzuki, M. Yamada, R. P. Rhoads, Jr., Y. Ikeuchi, and R. E. Allen. 2009. Possible implication of satellite cells in regenerative motoneuritogenesis: HGF upregulates neural chemorepellent Sema3A during myogenic differentiation. Am. J. Physiol. Cell Physiol. 297:C238-C252. 
Tatsumi, R., S. M. Sheehan, H. Iwasaki, A. Hattori, and R. E. Allen. 2001. Mechanical stretch induces activation of skeletal muscle satellite cells in vitro. Exp. Cell Res. 267:107-114.

Vega, R. A., H. G. Lee, H. Kuwayama, N. Matsunaga, and H. Hidari. 2002. Age-related changes in plasma leptin from early growing to late finishing stages of castrated Holstein steers: utilizing multi-species leptin RIA. Asian Australas. J. Anim. Sci. 15:725731.

Vernon, R. G. 2005. Lipid metabolism during lactation: a review of adipose tissue-liver interactions and the development of fatty liver. J. Dairy Res. 72:460-469.

Vernon, R. G., R. G. Denis, and A. Sorensen. 2001. Signals of adiposity. Domest. Anim. Endocrinol. 21:197-214.

Vicini, J. L., F. C. Buonomo, J. J. Veenhuizen, M. A. Miller, D. R. Clemmons, and R. J. Collier. 1991. Nutrient balance and stage of lactation affect responses of insulin, insulin-like growth factors I and II, and insulin-like growth factor-binding protein 2 to somatotropin administration in dairy cows. J. Nutr. 121: 1656-1664.

Wang, Y., F. Quagliarini, V. Gusarova, J. Gromada, D. M. Valenzuela, J. C. Cohen, and H. H. Hobbs. 2013. Mice lacking ANGPTL8 (Betatrophin) manifest disrupted triglyceride metabolism without impaired glucose homeostasis. Proc. Natl. Acad. Sci. USA 110:16109-16114.

Wegner, J., P. Huff, C. P. Xie, F. Schneider, F. Teuscher, P. S. Mir, Z. Mir, E. C. Kazala, R. J. Weselake, and K. Ender. 2001. Relationship of plasma leptin concentration to intramuscular fat content in beef from crossbred Wagyu cattle. Can. J. Anim. Sci. 81:451-457.

Wittamer, V., B. Bondue, A. Guillabert, G. Vassart, M. Parmentier, and D. Communi. 2005. Neutrophil-mediated maturation of chemerin: a link between innate and adaptive immunity. J. Immunol. 175:487-493.

Wittamer, V., J. D. Franssen, M. Vulcano, J. F. Mirjolet, E. Le Poul, I. Migeotte, S. Brezillon, R. Tyldesley, C. Blanpain, M. Detheux, A. Mantovani, S. Sozzani, G. Vassart, M. Parmentier, and D. Communi. 2003. Specific recruitment of antigen-presenting cells by chemerin, a novel processed ligand from human inflammatory fluids. J. Exp. Med. 198:977-985.

Wittamer, V., F. Gregoire, P. Robberecht, G. Vassart, D. Communi, and M. Parmentier. 2004. The C-terminal nonapeptide of mature chemerin activates the chemerin receptor with low nanomolar potency. J. Biol. Chem. 279:9956-9962.

Wozniak, A. C. and J. E. Anderson. 2007. Nitric oxide-dependence of satellite stem cell activation and quiescence on normal skeletal muscle fibers. Dev. Dyn. 236:240-250.

Wozniak, A. C., J. Kong, E. Bock, O. Pilipowicz, and J. E. Anderson. 2005. Signaling satellite-cell activation in skeletal muscle: markers, models, stretch, and potential alternate pathways. Muscle Nerve 31:283-300.
Xu, A., M. C. Lam, K. W. Chan, Y. Wang, J. Zhang, R. L. Hoo, J. Y. Xu, B. Chen, W. S. Chow, A. W. Tso, and K. S. Lam. 2005. Angiopoietin-like protein 4 decreases blood glucose and improves glucose tolerance but induces hyperlipidemia and hepatic steatosis in mice. Proc. Natl. Acad. Sci. USA 102: 60866091.

Yamada, M., Y. Sankoda, R. Tatsumi, W. Mizunoya, Y. Ikeuchi, K. Sunagawa, and R. E. Allen. 2008. Matrix metalloproteinase-2 mediates stretch-induced activation of skeletal muscle satellite cells in a nitric oxide-dependent manner. Int. J. Biochem. Cell Biol. 40:2183-2191.

Yamada, M., R. Tatsumi, T. Kikuiri, S. Okamoto, S. Nonoshita, W. Mizunoya, Y. Ikeuchi, H. Shimokawa, K. Sunagawa, and R. E. Allen. 2006. Matrix metalloproteinases are involved in mechanical stretch-induced activation of skeletal muscle satellite cells. Muscle Nerve 34:313-319.

Yamada, M., R. Tatsumi, K. Yamanouchi, T. Hosoyama, S. Shiratsuchi, A. Sato, W. Mizunoya, Y. Ikeuchi, M. Furuse, and R. E. Allen. 2010. High concentrations of HGF inhibit skeletal muscle satellite cell proliferation in vitro by inducing expression of myostatin: A possible mechanism for reestablishing satellite cell quiescence in vivo. Am. J. Physiol. Cell Physiol. 298:C465C476.

Yamauchi, E., Y. Suzuki, K.-H. So, K.-I. Suzuki, K. Katoh, and S.G. Roh. 2015. Single Nucleotide polymorphism in the coding region of bovine chemerin gene and their associations with carcass traits in Japanese black cattle. Asian Australas. J. Anim. Sci. 28:1084-1089.

Yamauchi, T., J. Kamon, H. Waki, Y. Terauchi, N. Kubota, K. Hara, Y. Mori, T. Ide, K. Murakami, N. Tsuboyama-Kasaoka, O. Ezaki, Y. Akanuma, O. Gavrilova, C. Vinson, M. L. Reitman, H. Kagechika, K. Shudo, M. Yoda, Y. Nakano, K. Tobe, R. Nagai, S. Kimura, M. Tomita, P. Froguel, and T. Kadowaki. 2001. The fat-derived hormone adiponectin reverses insulin resistance associated with both lipoatrophy and obesity. Nat. Med. 7:941946

Yi, P., J. S. Park, and D. A. Melton. 2013. Betatrophin: a hormone that controls pancreatic beta cell proliferation. Cell 153:747-758

Yonekura, S., S. Hirota, Y. Tokutake, M. T. Rose, K. Katoh, and H. Aso. 2014. Dexamethasone and acetate modulate cytoplasmic leptin in bovine preadipocytes. Asian Australas. J. Anim. Sci. 27:567-573.

Zhang, Y., R. Proenca, M. Maffei, M. Barone, L. Leopold, and J. M. Friedman. 1994. Positional cloning of the mouse obese gene and its human homologue. Nature 372:425-432.

Zieba, D. A., M. Amstalden, S. Morton, J. L. Gallino, J. F. Edwards, P. G. Harms, and G. L. Williams. 2003. Effects of leptin on basal and GHRH-stimulated GH secretion from the bovine adenohypophysis are dependent upon nutritional status. J. Endocrinol. 178:83-89. 